\title{
Hubungan Kadar Vitamin D dan Kadar C-Reactive Protein dengan Klinis Pasien Coronavirus Disease 2019
}

\author{
Catrien Berhandus, ${ }^{1}$ Jeffrey A. Ongkowijaya, ${ }^{2}$ Karel Pandelaki ${ }^{2}$
}

\author{
${ }^{1}$ Program Pendidikan Dokter Spesialis Bagian Ilmu Penyakit Dalam Fakultas Kedokteran \\ Universitas Sam Ratulangi, Manado, Indonesia \\ ${ }^{2}$ Bagian Ilmu Penyakit Dalam Fakultas Kedokteran Universitas Sam Ratulangi, Manado, \\ Indonesia \\ Email: catrieninterna2017@gmail.com
}

\begin{abstract}
COVID-19 patients could experience many respiratory symptoms accompanied with increased inflammatory markers, such as C-reactive protein (CRP). Vitamin D is known to have a positive effect on immune system by decreasing inflammatory process. This study was aimed to evaluate the relationship between vitamin D and CRP concentration and clinical severity, and the correlation between vitamin D concentration and CRP concentration in COVID-19 patients. This was an observational and analytical study with a cross-sectional design conducted at Prof. dr. R. D. Kandou hospital. A total of 40 subjects with COVID-19 were included. Clinical severity was classified into moderate and severe. All subjects underwent vitamin D and CRP concentration examination. The results showed that there was a significant relationship between vitamin D level and clinical severity of patients with COVID-19 ( $\mathrm{p}=0.0001)$. There was a significant relationship between CRP level and clinical severity of patients with COVID-19 $(\mathrm{p}=0.0001)$. Moreover, there was a negative correlation between vitamin $\mathrm{D}$ concentration and CRP concentration $(r=-0.49, \mathrm{p}=0.001)$. In conclusion, vitamin $\mathrm{D}$ insufficiency or deficiency is related to CRP increament and clinical severity of patients with COVID-19.
\end{abstract}

Keywords: coronavirus disease 2019, vitamin D, C-reactive protein (CRP), clinical severity

\begin{abstract}
Abstrak: Penderita COVID-19 mengalami berbagai gejala pernapasan disertai dengan peningkatan beberapa penanda inflamasi, salah satunya $C$-reactive protein (CRP). Vitamin D diketahui memiliki efek positif terhadap sistem imun tubuh dengan cara meredam proses inflamasi berlebihan. Penelitian ini bertujuan untuk mengetahui apakah terdapat hubungan antara kadar vitamin D dan kadar CRP dengan klinis COVID-19, dan korelasi antara kadar vitamin D dengan kadar CRP. Jenis penelitian ini ialah studi analitik observasional dengan desain potong lintang yang dilakukan di RSUP Prof. dr. R. D. Kandou. Total sampel sebanyak 40 pasien dengan diagnosis COVID-19. Gejala klinis pasien dibagi menjadi sedang dan berat. Pemeriksaan kadar vitamin D dan kadar CRP dilakukan pada seluruh sampel. Hasil penelitian mendapatkan hubungan bermakna antara kadar vitamin D dengan klinis pasien COVID-19 ( $\mathrm{p}=0,0001)$, dan antara kadar CRP dengan klinis pasien COVID-19 ( $\mathrm{p}=0,0001)$. Terdapat korelasi negatif antara kadar vitamin $\mathrm{D}$ dengan kadar CRP $(\mathrm{r}=-0,49, \mathrm{p}=0,001)$. Simpulan penelitian ini ialah insufisiensi atau defisiensi vitamin D berhubungan dengan peningkatan CRP dan klinis pasien COVID-19.

Kata kunci: coronavirus disease 2019, vitamin D, C-reactive protein (CRP), gejala klinis
\end{abstract}

\section{PENDAHULUAN}

Coronavirus Disease 2019 (COVID-

19) merupakan penyakit jenis baru yang belum pernah diidentifikasi sebelumnya pada manusia. Virus penyebab COVID-19 ini dinamakan Severe Acute Respiratory Syndrome Coronavirus 2 (Sars-CoV-2). Virus corona ialah jenis zoonosis, yaitu ditularkan antara hewan dan manusia. Pada tanggal 30 Januari 2020, World Health 
Organization (WHO) telah menetapkan COVID-19 sebagai Kedaruratan Kesehatan Masyarakat yang Meresahkan Dunia/Public Health Emergency of International Concern (KKMMD/PHEIC), dan pada tanggal 11 Maret 2020 ditetapkan sebagai pandemi. ${ }^{1}$ Peningkatan jumlah kasus COVID-19 berlangsung cukup cepat dan menyebar ke berbagai negara dalam waktu singkat, sampai dengan tanggal 15 Februari 2021 WHO melaporkan total kasus konfirmasi 108.579.352 dengan 2.396.408 kematian (Case Fatality Rate 2,2\%). Indonesia melaporkan kasus pertama pada tanggal 2 Maret 2020, dan jumlah kasus meningkat dan menyebar dengan cepat di seluruh wilayah Indonesia. Kementerian Kesehatan pada tanggal 15 Februari 2021 melaporkan sebanyak 1.223.930 kasus konfirmasi COVID19 dengan 33.367 kasus kematian (CFR $2,7 \%)^{2}$

Tanda dan gejala umum infeksi COVID-19 antara lain gejala gangguan pernapasan akut seperti demam, batuk dan sesak napas. Rerata masa inkubasi ialah 5-6 hari dengan masa inkubasi terpanjang 14 hari. ${ }^{1}$ Gejala pada fase awal umumnya ringan. Serangan kedua terjadi 4-7 hari setelah timbul gejala awal. Pada saat ini pasien masih demam dan mulai sesak, lesi di paru memburuk, penanda inflamasi mulai meningkat dan mulai terjadi hiperkoagulasi. Jika tidak teratasi, fase selanjutnya inflamasi makin tak terkontrol yang mengakibatkan acute respiratory distress syndrome (ARDS), sepsis, dan komplikasi lainnya., ${ }^{3,4}$ Selama perjalanan penyakit, evaluasi terhadap penanda inflamasi di antaranya peningkatan kadar C-Reactive Protein (CRP) serta interleukin-6 (IL-6) dapat membantu dalam penanganan pasien. ${ }^{5}$

Rekomendasi standar untuk mencegah penyebaran infeksi ialah melalui cuci tangan secara teratur menggunakan sabun dan air bersih, menerapkan etika batuk dan bersin, menghindari kontak secara langsung dengan ternak dan hewan liar, serta menghindari kontak dekat dengan siapapun yang menunjukkan gejala penyakit pernapasan seperti batuk dan bersin. ${ }^{6}$

Sebagai salah satu langkah pencegahan
COVID-19 yang terkait di bidang gizi yaitu konsumsi vitamin $\mathrm{D}$, sebab telah terbukti bahwa vitamin D memiliki efek positif terhadap sistem imun tubuh. ${ }^{7}$ Vitamin D memengaruhi beberapa jalur imun, dengan efek meningkatkan pertahanan mukosa dan secara bersamaan meredam inflamasi berlebihan. ${ }^{8,9}$ Dalam metaanalisis uji klinis acak terkontrol, Bergman et al ${ }^{10}$ menunjukkan bahwa vitamin $\mathrm{D}$ profilaksis mengurangi risiko perburukan infeksi saluran pernapasan (OR, 0,64; 95\%; CI, 0,49-0,84).

Kekurangan vitamin D adalah masalah kesehatan masyarakat global utama di semua kelompok usia. ${ }^{11}$ Vitamin D3 disintesis secara non-enzimatik dalam kulit selama paparan radiasi ultraviolet B (UVB) di bawah sinar matahari. Vitamin D3 tidak aktif dan membutuhkan konversi enzimatik di hati dan ginjal untuk membentuk bentuk aktif, 1,25-dihydroxy vitamin D. ${ }^{12}$

Daneshkhah et al ${ }^{13}$ melaporkan bahwa suplementasi vitamin D menurunkan risiko influenza. Studi yang memberikan hasil positif didukung dengan data bahwa wabah COVID-19 merebak pada musim dingin, saat dimana konsentrasi 25-hidroksivitamin D (25(OH)D) rendah. Insidensi kasus COVID-19 di belahan bumi bagian Selatan yang sedang berada pada akhir musim panas jauh lebih rendah. ${ }^{13}$ Penelitian Marik et al $^{11}$ mengasumsikan bahwa status vitamin D dapat memengaruhi risiko kematian akibat SARS-CoV-2. Tingkat kematian kasus spesifik COVID-19 negara-negara Eropa tertinggi di Italia, Spanyol, dan Perancis terjadi pada pasien dengan defisiennsi vitamin D berat. Hal ini menunjukkan bahwa kekurangan vitamin D sebagian dapat menjelaskan variasi geografis dalam tingkat kematian kasus COVID-19 yang dilaporkan dan menjelaskan bahwa suplementasi vitamin $\mathrm{D}$ dapat mengurangi kematian akibat pandemi ini. ${ }^{13}$

Di Indonesia, khususnya Sulawesi Utara angka kasus positif dan angka kematian COVID-19 terus bertambah. Berdasarkan tingginya kasus COVID-19 di daerah Sulawesi Utara, maka penulis tertarik untuk meneliti hubungan kadar vitamin D dan kadar CRP dengan klinis pasien COVID-19. 


\section{METODE PENELITIAN}

Penelitian ini dilaksanakan di RSUP Prof. dr. R. D. Kandou Manado. Penelitian dilakukan dalam rentang waktu 6 bulan mulai Juli 2020 s/d Desember 2020. Penelitian ini bersifat observasional analitik dengan desain studi potong lintang. Populasi penelitian ini ialah subjek COVID-19 yang dirawat di ruang perawatan isolasi RSUP Prof. dr. R. D. Kandou Manado yang memenuhi kriteria inklusi dan eksklusi. Metode pengambilan sampel secara consecutive sampling, yaitu semua subjek COVID-19 yang masuk dan dirawat di ruang perawatan isolasi RSUP Prof. dr. R. D. Kandou Manado. Kriteria inklusi penelitian ialah subjek COVID-19, laki-laki dan perempuan usia minimal 18 tahun, dan bersedia mengikuti penelitian, sedangkan kriteria ekslusi ialah pasien yang menggunakan suplementasi vitamin D dan riwayat penyakit autoimun. Penelitian ini dilakukan dalam tiga tahap. Tahap pertama ialah menjaring subjek dewasa berusia 18 tahun ke atas yang terinfeksi COVID-19 berdasarkan anamnesis, pemeriksaan fisik, penunjang, dan catatan medik. Subjek yang memenuhi kriteria diberi penjelasan tentang penelitian, dan yang bersedia, diminta menandatangani informed consent dan dilakukan pencatatan identitas dan karakteristik subjek. Tahap kedua, subjek yang memenuhi kriteria inklusi dan tidak didapatkan kriteria eksklusi dilakukan pemeriksaan kadar CRP dan kadar vitamin D. Tahap ketiga, dilakukan analisis data. Data yang diperoleh dianalisis dengan menggunakan program melalui perangkat komputer. Uji statistik yang digunakan ialah analisis deskriptif secara umum dengan metode univariat untuk mendapatkan nilai minimum, maksimum, rerata, dan simpang baku, serta distribusi dari semua variabel. Untuk mendapatkan nilai korelasi antara kadar vitamin D dan kadar CRP digunakan uji korelasi Pearson pada sebaran data normal dan uji Spearman pada sebaran data tidak normal, sedangkan untuk mengetahui hubungan antara kadar vitamin D dan CRP dengan klinis pasien COVID-19 digunakan uji Chi-square. Untuk mengetahui sebaran data normal atau tidak normal digunakan Uji Shapiro-Wilks. Hasil penelitian dinarasikan dan diperjelas dalam bentuk tabel.

\section{HASIL PENELITIAN}

Penelitian ini dilaksanakan di RSUP Prof. dr. R. D. Kandou Manado dalam rentang waktu 6 bulan mulai Juli 2020 sampai Desember 2020. Pada penelitian ini didapatkan 40 sampel dengan subjek pasien COVID-19 yang memenuhi kriteria inklusi dan kriteria eksklusi, terdiri dari 23 orang $(57,5 \%)$ laki-laki dan 17 orang $(42,5 \%)$ perempuan.

Tabel 1 memperlihatkan karakteristik umum subyek penelitian. Rerata usia subyek pada penelitian ini ialah $54,5 \pm 14,66$ tahun, rerata kadar Vitamin D 27,66 $\pm 10,35$, dan rerata kadar CRP 23,72 $\pm 20,54$.

Tabel 2 memperlihatkan distribusi subyek berdasarkan gejala klinis COVID19. Subjek yang menunjukkan gejala COVID-19 gejala berat berjumlah 22 orang $(55 \%)$ lebih banyak dibandingkan subjek yang menunjukkan gejala sedang yaitu 18 orang $(45 \%)$.

Tabel 3 memperlihatkan hasil uji Chisquare terhadap hubungan antara kadar vitamin D dengan gejala klinis COVID-19 sedang dan berat yang mendapatkan adanya hubungan bermakna antara kadar vitamin D dengan gejala klinis COVID-19 ( $\mathrm{p}<0,05)$.

Tabel 4 memperlihatkan hasil uji Chisquare terhadap hubungan antara kadar CRP dengan gejala klinis COVID-19 ringan dan berat yang mendapatkan adanya hubungan bermakna antara kadar CRP dengan gejala klinis COVID-19 $(p<0,05)$

Analisis hubungan antara kadar vitamin D dengan kadar CRP menggunakan uji Shapiro-Wilkinson untuk normalitas data yang mendapatkan sebaran data tidak normal, sehingga untuk melihat adanya hubungan antara kadar vitamin D dengan kadar CRP dilakukan uji Spearman. Hasil uji korelasi Spearman mendapatkan korelasi (r) sebesar $-0,49$ dengan nilai $p=0,001$ yang menunjukkan bahwa terdapat hubungan negatif bermakna antara kadar vitamin D dengan kadar CRP. Koefisien korelasi menunjukkan bahwa kadar vitamin D 
Tabel 1. Karakteristik subjek penelitian

\begin{tabular}{lcccccc}
\hline Variabel & n & Min & Maks & Median & Rerata & SB \\
\hline Usia & 40 & 23 & 84,00 & 56 & 54,5 & 14,66 \\
Vitamin D & 40 & 9,10 & 55,90 & 26,15 & 27,66 & 10,35 \\
CRP & 40 & 4,00 & 52,00 & 12,00 & 23,72 & 20,54 \\
\hline
\end{tabular}

$\mathrm{n}=$ jumlah sampel, $\mathrm{SB}=$ simpang baku

Tabel 2. Karakteristik subjek penelitian berdasarkan gejala klinis COVID-19

\begin{tabular}{lcc}
\hline Variabel & n & \% \\
\hline Gejala berat & 22 & 55 \\
Gejala sedang & 18 & 45 \\
Total & 40 & 100 \\
\hline
\end{tabular}

$\mathrm{n}=$ jumlah sampel, $\%=$ persentase

Tabel 3. Hubungan kadar vitamin D dengan klinis COVID-19

\begin{tabular}{|c|c|c|c|c|c|}
\hline & & \multicolumn{2}{|c|}{ Klinis COVID-19 } & \multirow[t]{2}{*}{ Total } & \multirow[t]{2}{*}{$\mathbf{p}^{*}$} \\
\hline & & Sedang & Berat & & \\
\hline \multirow[t]{2}{*}{ Vitamin D } & Normal & $12(92,3 \%)$ & $1(7,7 \%)$ & $13(100 \%)$ & 0,0001 \\
\hline & Rendah & $6(22,2 \%)$ & $21(77,8 \%)$ & $27(100 \%)$ & \\
\hline Total & & $18(45 \%)$ & $22(55 \%)$ & $40(100 \%)$ & \\
\hline
\end{tabular}

$*=$ Uji Chi-square $; \mathrm{p}=$ kemaknaan

Tabel 4. Hubungan kadar CRP dengan klinis COVID-19

\begin{tabular}{|c|c|c|c|c|c|}
\hline & & \multicolumn{2}{|c|}{ Klinis COVID-19 } & \multirow[t]{2}{*}{ Total } & \multirow[t]{2}{*}{$\mathbf{p}^{*}$} \\
\hline & & Sedang & Berat & & \\
\hline \multirow[t]{2}{*}{ CRP } & Normal & $14(100 \%)$ & $0(0 \%)$ & $14(100 \%)$ & 0,0001 \\
\hline & Tinggi & $4(15,4 \%)$ & $22(84,6 \%)$ & $26(100 \%)$ & \\
\hline Total & & $18(45 \%)$ & $22(55 \%)$ & $40(100 \%)$ & \\
\hline
\end{tabular}

* = uji Chi-square $; \mathrm{p}=$ kemaknaan

memiliki tingkat hubungan sedang dan berbanding terbalik dengan kadar CRP, yaitu semakin rendah kadar vitamin $\mathrm{D}$, maka semakin tinggi kadar CRP, demikian pula sebaliknya.

\section{BAHASAN}

Rerata usia yang dilaporkan pada penelitian ini ialah 54,5 tahun, sedikit lebih rendah dibandingkan studi yang dilakukan di Wuhan terhadap 99 penderita COVID-19 dengan rerata usia 55,5 tahun. ${ }^{14}$ Nilai ini juga berbeda dengan studi sebelumnya yang dilakukan di Jakarta dan Singapura.
Studi yang dilakukan di Jakarta pada 582 pasien positif COVID-19 menunjukkan rerata usia 44,5 tahun, ${ }^{15}$ sedangkan studi yang dilakukan di Singapura pada 100 pasien positif COVID-19 menunjukkan rerata usia 42,5 tahun. ${ }^{16}$ Goldstein et $\mathrm{al}^{17}$ meneliti sembilan studi dan mendapatkan kerentanan terhadap infeksi yang lebih tinggi pada kelompok dewasa dibandingkan anak-anak. Kerentanan terhadap infeksi tertinggi terjadi pada kelompok pasien berusia $>60$ tahun. Selain itu, pada kelompok dewasa juga didapatkan tingkat transmisi yang lebih tinggi. Hal ini disebabkan 
durasi proses viral shedding yang lebih lama pada orang dewasa. Faktor lain yang dapat menyebabkan tingginya jumlah kasus pada kelompok usia dewasa ialah munculnya berbagai komorbiditas pada usia tersebut disertai dengan mobilitas dan interaksi yang tinggi di lingkungan kerja. ${ }^{17}$

Jumlah subjek laki-laki lebih tinggi dibandingkan perempuan $(57,5 \%$ banding $42,5 \%$ ). Nilai ini selaras dengan studi yang dilakukan di Jakarta dengan jumlah laki-laki sebanyak $59 \%$ dan perempuan sebanyak $41 \% .{ }^{14}$ Studi-studi sebelumnya menunjukkan bahwa perempuan lebih tidak rentan terhadap infeksi virus. Perempuan memiliki aktivitas makrofag dan neutrofil disertai respons dan produksi antibodi yang lebih tinggi. Selain itu, angiotensin converting enzyme 2 (ACE2) ditemukan dalam ekspresi yang lebih tinggi pada ginjal laki-laki dibandingkan perempuan. Hal ini dapat menjelaskan mengapa laki-laki memiliki kerentanan yang lebih tinggi terhadap infeksi COVID19 dibandingkan perempuan. ${ }^{18}$

Terdapat lebih banyak pasien dengan gejala klinis berat dibandingkan gejala sedang (55\% banding $45 \%)$. Gejala klinis berat ditandai dengan adanya gambaran pneumonia. Studi yang dilakukan di Jakarta menunjukkan terdapat lebih banyak penderita dengan gejala sedang berat yang membutuhkan perawatan di rumah sakit dibandingkan penderita dengan gejala ringan dan tanpa gejala (berturut-turut $44 \%, 34 \%$, dan $22 \%) .{ }^{15}$ Data dari World Health Organization (WHO) melaporkan bahwa jumlah kasus tanpa gejala atau gejala ringan sebesar $80 \%$, sedangkan jumlah kasus gejala berat ialah $15 \%$, dan jumlah kasus kritis yang membutuhkan suplementasi oksigen ialah 5\%. ${ }^{19}$ Tingginya jumlah kasus dengan gejala berat pada penelitian ini disebabkan oleh lokasi pengambilan sampel seluruhnya ialah pasien yang dirawat di rumah sakit sehingga tidak dapat menggambarkan sebaran derajat keparahan kasus COVID19 yang sesungguhnya di masyarakat.

Pengukuran kadar vitamin D menunjukkan sebanyak $67,5 \%$ pasien mengalami defisiensi atau insufisiensi vitamin D. Hasil serupa juga ditemukan pada studi yang dilakukan di Turki terhadap 149 pasien COVID-19. Karahan dan Katkat ${ }^{20}$ mendapatkan sebanyak $22,8 \%$ pasien mengalami insufisiensi sementara $69,1 \%$ mengalami defisiensi vitamin D. Kadar vitamin D juga ditemukan lebih rendah secara bermakna pada pasien dengan gejala klinis berat dibandingkan yang bergejala ringan. Pasien yang meninggal juga memiliki nilai vitamin D yang lebih rendah dibandingkan pasien yang bertahan hidup. Regresi logistik multivariat pada penelitian yang dilakukan Karahan dan Katkat menunjukkan kadar vitamin D serum berhubungan dengan peningkatan mortalitas pada pasien COVID-19.

Rendahnya kadar vitamin D dalam tubuh menyebabkan penurunan fungsi imun sehingga meningkatkan kerentanan terhadap infeksi. Telah diketahui bahwa vitamin D mempunyai peran penting dalam regulasi sistem imun baik sistem imun bawaan dan adaptif. Dari sisi regulasi sistem imun bawaan, vitamin $\mathrm{D}$ dapat meningkatkan kemampuan fagositosis dari makrofag serta meningkatkan pengenalan terhadap patogen melalui toll-like receptor. Proses ini menjadi penghubung antara sistem imun bawaan dengan sistem imun adaptif sehingga terjadi aktivasi respon imun adaptif melalui stimulasi produksi limfosit $\mathrm{T}$ dan B. Vitamin D juga mendukung sistem imun bawaan melalui sekresi peptida antimikroba seperti defensins dan cathelicidin. $^{21}$

Badai sitokin merupakan proses yang berperan penting dalam menyebabkan perburukan pasien COVID-19. Secara teoritis, vitamin $\mathrm{D}$ mempunyai peranan penting pada penghambatan badai sitokin karena vitamin D merupakan suatu imunomodulator, yang berarti memiliki efek imunostimulan dan imunosupresif pada keadaan tertentu. Vitamin D menghambat pelepasan sitokin proinflamasi dari sel Th1 seperti TNF-alfa dan interferon-gamma. Selain itu, vitamin ini menghambat produksi interlukin 12, yaitu suatu sitokin inflamasi yang berperan dalam proliferasi sel limfosit. Vitamin D juga melakukan penghambatan Th17 yang berkaitan dengan 
proinflamasi dan berperan dalam menghambat aktivasi sel limfosit B dan sintesis immunoglobulin. Vitamin D akan meningkatkan produksi sel $\mathrm{T}$ regulator yang berperan dalam sekresi sitokin anti inflamasi IL10 dan meningkatkan produksi Th2 dibandingkan Th1. ${ }^{22}$ Selain itu, kalsitriol yang merupakan bentuk aktif vitamin D juga menimbulkan efek menguntungkan pada sistem imun adaptif. Kalsitriol menstimulasi limfosit $\mathrm{T}$ regulator dan menekan pelepasan sitokin dari sel Th1 dan Th2. ${ }^{20}$ Berdasarkan hal tersebut, vitamin D dapat menyebabkan terjadinya penurunan kerusakan target organ akibat badai sitokin, sehingga diharapkan gejala klinis yang lebih ringan pada pasien COVID-19 dengan kadar vitamin D normal.

Suplementasi vitamin D dapat mengurangi risiko infeksi COVID-19. Dosis vitamin D yang dianjurkan ialah 10.000 IU per hari selama beberapa minggu untuk meningkatkan konsentrasi vitamin D secara cepat dilanjutkan dengan dosis 5.000 IU per hari. Target konsentrasi vitamin D ialah 40-60 ng/mL. Pada pasien yang sudah terinfeksi COVID-19, suplementasi vitamin $\mathrm{D}$ dengan dosis yang lebih tinggi mungkin dapat bermanfaat. ${ }^{7}$

Pada penelitian ini didapatkan peningkatan CRP pada $65 \%$ subjek dengan median kadar CRP ialah $12 \mathrm{mg} / \mathrm{L}$. Uji Chi-Square menunjukkan terdapat hubungan bermakna antara kadar CRP dengan klinis pasien COVID-19 ( $\mathrm{p}<0,05)$. Studi-studi sebelumnya melaporkan adanya hubungan antara nilai CRP dengan tingkat keparahan penyakit. ${ }^{23}$ Pada penelitian oleh Guan et $\mathrm{al}^{4}$ di Cina yang melibatkan 1.099 pasien COVID-19, didapatkan bahwa pasien dengan COVID-19 berat mempunyai kadar CRP 44,5\% lebih tinggi dibandingkan pasien COVID-19 dengan gejala ringan. ${ }^{4}$ Wang et $\mathrm{al}^{23}$ mendapatkan nilai CRP secara berturut-turut lebih tinggi pada kelompok dengan gejala kritis, gejala berat, gejala sedang, dan gejala ringan.

C-Reactive Protein (CRP) merupakan protein yang diproduksi tubuh sebagai respons terhadap inflamasi. Protein ini terutama dihasilkan di hati sebagai respons terhadap inflamasi dan dapat menjadi suatu penanda derajat beratnya suatu keadaan inflamasi sistemik. Pothempa et $\mathrm{al}^{24}$ menyatakan bahwa CRP akan meningkat dalam waktu 6-10 jam dari paparan kejadian kerusakan jaringan yang umumnya terjadi sebagai akibat respons inflamasi. ${ }^{24}$ Selain itu, CRP membantu aktivasi komplemen dan meningkatkan fagositosis sehingga membantu pembersihan mikroorganisme patogen dari tubuh. ${ }^{23}$ Dapat disimpulkan bahwa CRP merupakan suatu biomarker penanda pasien dengan gejala berat dan dapat digunakan untuk menentukan prognosis pasien. Pemeriksaan CRP pada tahap awal dapat digunakan sebagai suatu masukan dalam panduan penatalaksanaan lebih lanjut.

Penelitian ini menunjukkan bahwa terdapat korelasi negatif yang bermakna antara kadar vitamin D dengan kadar CRP $(\mathrm{r}=-0,49, \mathrm{p}=0,001)$. Studi yang dilakukan oleh Daneshkhah et $\mathrm{al}^{13}$ juga mendapatkan korelasi negatif antara kadar vitamin D dengan CRP pada pasien lanjut usia yang terdiagnosis COVID-19. Subjek dengan defisiensi vitamin D memiliki OR 1,8 untuk terjadinya peningkatan CRP. ${ }^{13}$ Penelitian lain oleh Maghbooli et $\mathrm{al}^{22}$ yang melibatkan 325 pasien COVID-19 menunjukkan bahwa $74 \%$ di antaranya merupakan COVID-19 berat dan hanya sebanyak $32,8 \%$ yang memiliki kadar Vitamin D dalam jumlah cukup. Studi ini juga menunjukkan bahwa pasien dengan kadar vitamin D cukup memiliki kadar CRP serum yang lebih rendah dibandingkan dengan yang memiliki kadar vitamin D kurang (61 [47] vs. 77,2 [122]; $p=0,01)$. Analisis lebih lanjut menunjukkan bahwa pada pasien defisiensi vitamin $\mathrm{D}$ dengan kadar CRP yang tinggi ( $>40 \mathrm{mg} / \mathrm{L}$ ) memiliki risiko 1,7 kali lebih tinggi untuk terkena COVID-19 berat. $^{22}$ Temuan serupa juga didapatkan pada studi-studi yang menilai hubungan antara kadar vitamin D dengan kadar CRP pada berbagai populasi. Poudel-Tandukar et $\mathrm{al}^{25}$ menilai hubungan antara kadar vitamin D dan CRP pada 316 pasien positif HIV. Analisis dengan regresi logistik menunjukkan bahwa subjek dengan kadar 
vitamin $\mathrm{D}<20 \mathrm{ng} / \mathrm{ml}$ memiliki OR 3,2 dalam terjadinya peningkatan $\mathrm{CRP}>3$ $\mathrm{mg} / \mathrm{L}$ dibandingkan subjek dengan kadar vitamin $\mathrm{D}>20 \mathrm{ng} / \mathrm{ml}$. Studi lain yang dilakukan pada subjek dengan poliartritis inflamasi menunjukkan bahwa peningkatan kadar vitamin D sebesar $10 \mathrm{ng} / \mathrm{ml}$ berhubungan dengan penurunan kadar CRP sebesar $25 \% .{ }^{26}$ Studi pada subjek dengan obesitas menunjukkan terdapat korelasi negatif antara kadar vitamin D dengan kadar CRP. ${ }^{27}$ Uji klinis yang dilakukan oleh Schleithoff et $\mathrm{al}^{28}$ pada pasien dengan gagal jantung kongestif menunjukkan bahwa suplementasi vitamin $\mathrm{D}$ dapat mengurangi kadar CRP dan biomarker inflamasi lainnya secara bermakna.

Hasil penelitian ini menunjukkan bahwa terdapat efek protektif dari vitamin D terhadap inflamasi. Mekanisme terjadinya efek protektif ini dapat dijelaskan melalui peran vitamin ini sebagai imunomodulator dalam merespons kondisi inflamasi sistemik. Vitamin D menyebabkan terjadinya regulasi produksi sitokin dari limfosit dan juga down-regulation aktivasi faktor Nf-kB yang mengkode berbagai sitokin proinflamasi. ${ }^{25}$ Defisiensi vitamin $\mathrm{D}$ diketahui berhubungan dengan peningkatan produksi sitokin seperti TNFalfa dan interleukin-1 beta, sehingga berkaitan dengan keadaan proinflamasi dan peningkatan kadar CRP. Vitamin D juga diketahui dapat memengaruhi bioaktivitasi dari IL-6 untuk mengurangi stimulasi dari produksi sitokin proinflamasi. Selain itu, vitamin D menstimulasi pelepasan sitokin antiinflamasi seperti IL-10 dan menekan sekresi sitokin proinflamasi seperti IL-17. Efek antiinflamasi menjadi dampak positif bagi pencegahan terjadinya badai sitokin pada pasien COVID-19 sehingga menurunkan kerusakan target organ dan angka kematian. Hal ini berujung pada penurunan inflamasi sistemik dan ditandai dengan penurunan kadar CRP. ${ }^{22}$

\section{SIMPULAN}

Terdapat hubungan bermakna antara kadar vitamin $\mathrm{D}$ dengan klinis pasien COVID-19 yang artinya semakin tinggi kadar vitamin D maka klinis pasien COVID-19 tergolong ringan atau sedang, begitu juga sebaliknya. Terdapat hubungan bermakna antara kadar CRP dengan klinis pasien COVID-19 yang artinya semakin tinggi kadar CRP maka klinis pasien COVID-19 tergolong berat, begitu juga sebaliknya. Terdapat hubungan negatif bermakna antara kadar vitamin D dan kadar CRP pada pasien COVID-19, yaitu didapatkan kadar vitamin $\mathrm{D}$ yang rendah dengan kadar CRP yang tinggi dan sebaliknya.

\section{Konflik Kepentingan}

Penulis menyatakan tidak terdapat konflik kepentingan dalam studi ini

\section{DAFTAR PUSTAKA}

1. Direktorat Jendral Pencegahan dan Pengendalian Penyakit. Pedoman Pencegahan dan Pengendalian Coronavirus. Jakarta: Kementerian Kesehatan RI, 2020.

2. Kementerian Kesehatan Republik Indonesia. Info infeksi emerging: situasi terkini perkembangan Coronavirus Disease (COVID-19) [Internet]. Kemenkes RI. 2021 [update 15 Februari 2021]. Available from: https://covid19. kemkes.go.id/category/situasi-infeksiemerging/infocorona-virus/.

3. Huang C, Wang Y, Li X, Ren L, Zhao J, Hu Y, et al. Clinical features of patients infected with 2019 novel coronavirus in Wuhan, China. Lancet. 2020;395 (10223):497-506.

4. Guan WJ, Ni ZY, Hu Y, Liang WH, Ou CQ, He JX et al. Clinical characteristics of coronavirus disease 2019 in China. N Engl J Med. 2020:NEJMoa20002032.

5. Qin C, Zhou L, Hu Z, Zhang S, Yang S, Tao $\mathrm{Y}$, et al. Dysregulation of immune response in patients with coronavirus 2019 (COVID-19) in Wuhan, China. Clin Infect Dis. 2020;71(15):762-8.

6. World Health Organization. Global surveillance for human infection with novelcoronavirus (2019-ncov) [Internet]. WHO. 2020 [cited 2020 June 9]. Available from: https://www.who.int/ publications-detail/global-surveillance for-human-infection-with-novelcoronavirus-(2019-ncov) 
7. Grant WB, Lahore H, McDonell SL, Baggerly CA, French CB, Aliano JL, et al. Evidence that vitamin D supplementation could reduce risk of influenza and COVID-19 infections and deaths. Nutrients. 2020;12(4):988.

8. Khare D, Godbole NM, Pawar SD. Calcitriol $[1,25[\mathrm{OH}] 2 \mathrm{D} 3]$ pre- and post-treatment suppresses inflammatory response to influenza A (H1N1) infection in human lung A549 epithelial cells. Eur J Nutr. 2013;52:1405-15.

9. Parlak E, Erturk A, Cag E. The effect of inflammatory cytokines and the level of vitamin $\mathrm{D}$ on prognosis in CrimeanCongo hemorrhagic fever. Int $\mathrm{J}$ Clin Exp Med. 2015;8:18302-10.

10. Bergman P, Lindh AU, Bjorkhem-Bergman L. Vitamin D and respiartory tract infections: A systematic review and meta-analysis of randomized controlled trials. PloS ONE. 2013;8(6):e65835.

11. Marik P, Kory P, Varon J. Does vitamin D status impact mortality from Sars-CoV2 Infection. Med Drug Discov. 2020;6:100041. Doi: https://doi.org/ 10.1016/j. medidd.2020.100041

12. McLaughlin J, Holick MF. Aging decreases the capacity of human skin to produce vitamin D3. J Clin Invest. 1985;76: 1536-8.

13. Daneshkhah A, Eshein A, Subramanian H. The possible role of vitamin $\mathrm{D}$ in suppressing cytokine storm of COVID19 patients and associated mortality. MedRxiv. 2020. Doi: https://doi. org/ 10.1101/2020.04.08.20058578

14. Chen N, Zhou M, Dong X, Qu J, Gong F, Han Y. Epidemiological and clinical characteristics of 99 cases of 2019 novel coronavirus pneumonia in Wuhan, China: a descriptive study. Lancet. 2020;395(10223):507-13.

15. Ibrahim F, Natasha A, Saharman YR, Sudarmono P. Preliminary report of COVID19 testing: experience of the clinical microbiology laboratory of Universitas Indonesia, Jakarta, Indonesia. New Microbes New Infect. 2020;37:100733.

16. Ng Y, Li Z, Chua Y.X, Chaw W.L, Zhao Z, Er B. Evaluation of the effectiveness of surveillance and containment measures for the first 100 patients with COVID19 in Singapore - January 2 February 29, 2020. Morb Mortal Wkly Rep
(MMWR). 2020;69:307-11.

17. Goldstein E, Lipsitch M, Cevik M. On the effect of age on the transmission of SARS-CoV-2 in households, schools and the community. J Infect Dis. 2020; 29:jiaa691.

18. Kopel J, Perisetti A, Roghani A, Aziz M, Gajendran M, Goyal H. Racial and gender-based differences in COVID19. Front Public Health. 2020;8:418.

19. WHO. Coranavirus disease 2019 (COVID19) situation report -46 [Internet]. WHO. 2020 [cited 2020 November 8]. Available from: https://www.who.int/ docs/default-source/coronaviruse/ situation-reports/20200306-sitrep-46covid-19.pdf?sfvrsn=96b04adf_4

20. Karahan S, Katkat F. Impact of serum $25(\mathrm{OH})$ vitamin D level on mortality in patients with COVID-19 in Turkey. J Nutr Health Aging. 2020;5:1-8.

21. Siddiqui M, Manansala JS, Abdulrahman HA, Nasrallah GK, Smatti MK, Younes $\mathrm{N}$, et al. Immune modulatory effects of vitamin $\mathrm{D}$ on viral infection. Nutrient. 2020;12(9):2879.

22. Maghbooli Z, Sahraian MA, Ebrahimi M, Pazozkei M, Kafan S, Tabriz HM, et al. Vitamin D sufficiency, a serum 25hydroxy vitamin D at least $30 \mathrm{ng} / \mathrm{ml}$ reduced risk for adverse clinical outcomes in patients with COVID-19 infection. pLoS One. 2020:15(9): e0239799.

23. Wang L. C-reactive protein levels in the early stage of COVID-19. Med Mal Infect. 2020;50(4):332-4.

24. Pothempa LA, Rajab IM, Hart PC, Bordon J, Fernandez-Botran R. Insights into the use of C-reactive protein as a diagnostic index of disease severity in COVID-19 infections. ASTMH. 2020;103(2):561-3.

25. Poudel-Tandukar K, Poudel KC, Jimba M, Kobayashi J, Johnson CA, Palmer PH. Serum 25-hydroxy vitamin D levels and C-reactive protein in persons with human immunodeficiency virus infection. AIDS Res Hum Retroviruses. 2013;29(3):528-34.

26. Patel S, Farragher T, Berry J, Bunn D, Silman A, Symmons D. Association between serum vitamin D metabolite levels and disease activity in patients with early inflammatory polyarthritis. Arthritis Rheum. 2007;56(7):2143-9 
27. Bellia A, Garcovich C, D'Adamo M, Lombardo M, Tesauro M, Donadel G, et al. Serum 25-hydroxy vitamin D levels are inversely associated with systemic inflammation in severe obese subjects. Intern Emerg Med. 2013; 8(1):33-40.
28. Schleithoff SS, Zittermann A, Tenderich G, Berthold HK, Stehle P, Koerfer R. Vitamin D supplementation improves cytokine profiles in patients with congestive heart failure: a double-blind, randomized, placebo-controlled trial. Am J Clin Nutr. 2006 Apr; 83(4):754-9. 